Article

\title{
Developing a Design-Led Approach for the Food-Energy-Water Nexus in Cities
}

\author{
Wanglin Yan ${ }^{1,2, *}$ and Rob Roggema ${ }^{3,4}$ \\ ${ }^{1}$ Faculty of Environment and Information Studies, Keio University, 252-0816 Kanagawa, Japan; E-Mail: yan@sfc.keio.ac.jp \\ 2 Graduate School of Media and Governance, Keio University, 252-0816 Kanagawa, Japan \\ ${ }^{3}$ Office for Adaptive Planning and Design, Cittaideale, 6706 LC Wageningen, The Netherlands; E-Mail: rob@cittaideale.eu \\ ${ }^{4}$ Knowledge Centre NoorderRuimte, Hanze University Groningen, 9747 AS Groningen, The Netherlands \\ * Corresponding author
}

Submitted: 11 September 2018 | Accepted: 26 November 2018 | Published: 21 February 2019

\begin{abstract}
Urban communities are particularly vulnerable to the future demand for food, energy and water, and this vulnerability is further exacerbated by the onset of climate change at local. Solutions need to be found in urban spaces. This article based around urban design practice sees urban agriculture as a key facilitator of nexus thinking, needing water and energy to be productive. Working directly with Urban Living Labs, the project team will co-design new food futures through the moveable nexus, a participatory design support platform to mobilize natural and social resources by integrating multi-disciplinary knowledge and technology. The moveable nexus is co-developed incrementally through a series of design workshops moving around living labs with the engagement of stakeholders. The methodology and the platform will be shared outside the teams so that the knowledge can be mobilized locally and globally.
\end{abstract}

\section{Keywords}

energy; food; moveable nexus; nexus thinking; participatory design; urban design; water

\section{Issue}

This article is part of the issue "The City of Flows: Urban Planning of Environmental Flows", edited by Rob Roggema (Cittaideale, The Netherlands/Hanze University Groningen, The Netherlands).

(C) 2019 by the authors; licensee Cogitatio (Lisbon, Portugal). This article is licensed under a Creative Commons Attribution 4.0 International License (CC BY).

\section{Introduction}

This is a century of cities (Nature, 2010). More than 50\% of the world's population lives in cities, and this number is expected to reach $68 \%$ in 2050 (UN, 2018). As a result, the demand for food, energy and water (collectively referred to as FEW) as well as land is expected to increase even more, leading to concerns about crossing critical thresholds of capacity at all scales (Hoff, 2011), and eventually exceeding planetary limits (Steffen et al., 2015). In developing countries, it can be a challenge to shelter an adequate quantity and quality of FEW from environmental pollution and ecological system degradation (Abdul, Shrestha, Pandey, \& Anal, 2017; NDRC, 2008; Siddiqi \& Anadon, 2011). In developed countries, where the social infrastructure is generally well-developed and living environment is maintained, FEW issues are not typically discussed as day-to-day concerns. Citizens mostly see FEW provisions as a given, and often do not show any particular interest except the bills, although both in regular times as well as in preparation for disasters and accidents governments and urban utility sectors are constantly challenged to be able to provide stable, sustainable and prevalent FEW services (Romero-lankao, Mcphearson, \& Davidson, 2017). Recently, with progressing climate change, aging population, and deteriorating infrastructure, there is a growing awareness of risks to the sustainability of FEW in cities (IPCC, 2014; Moss et al., 2010), in the developed world (IRENA, 2015; White, Wutich, Larson, \& Lant, 2015). 
Sustainability of cities has been studied for long. However, the prevailing model of urban sustainability is too narrow (Powell, 2016). Planners and designer often work on sustainability, driven by specific techniques such as a smart energy system, the Edible City (Bohn \& Viljoen, 2011), or design of green paths and rooftop gardens (Engelhard, 2010), etc., motivated by professional skills. Policy makers usually address single issues in a single administrative division even though the social, economic and ecological factors that present as problems of sustainability are in fact intertwined at all scales (Powell, 2016) and across sectors. The awareness of a nexus in FEW sectors is often weak. In fact, FEW are highly intertwined, even parametrically related. There are tradeoffs and synergistic effects (Haase, Haase, \& Rink, 2014; Vogt et al., 2010). This situation is referred to as the FEWnexus. Due to the connectedness of FEW in social and ecological systems, a nexus approach could improve sustainability in general terms and, as a result, has attracted attention as a way to challenge the complex urban issues related to the status quo (Liu et al., 2018). The idea can be traced to works by Ignacy Sachs in the late 1970s and early 1980s, in particular with reference to the food and energy nexus at the United Nations University FoodEnergy Program (Sachs, 1980, 1988). The World Bank worked on the food, water and trade nexus (McCalla, 1997) and later replaced the idea with new concepts, including virtual water, at the Kyoto World Water Forum in 2003 (Allan, 2003a; Merrett, 2003). The importance of the three nexus pillars of FEW was officially recognized at the first Nexus Conference in Bonn, Germany, 2011 (Hoff, 2011), making that year Nexus Year One. Since then, our understanding on the nexus has been seriously improved. The essence of the nexus thinking is about doing more with less by improving the efficiency of investment in resources and land-use (Hoff, 2011; Kurian \& Ardakanian, 2015; Martínez-Martínez \& Calvo, 2010). Understanding and acting upon this concept is central to diminishing the human footprint on planetary boundaries (Kurian \& Ardakanian, 2015). However, "the application and implementation of a nexus approach is in its infancy" (Liu et al., 2018). This is particularly true in urban contexts. Most research is focused on the supply side of the equation, namely on how to secure FEW resources in response to a growing global demand. Few studies delve deeply into urban space and design solutions from the perspective of end users and consumers.

Working on sustainable solutions for FEW requires a strategic understanding of the urban nexus. The European Union initiated the Urban Nexus Project in FP7 (the 7th Framework Program, funded by the EU Research Funding 2007-2013) from 2011 to 2014. The project examined urban issues through a nexus approach and published a series of reports. The major finding of the project is that FEW in cities is not only an issue of resources but also of land use, resilience, and eventually the quality of life of a city's urban populace (Urban Nexus, 2013a, 2013b, 2013c). FEW is a wicked problem in consideration of the complexity of cities and related to many urban problems. However, governmental sectors or utility agencies typically treat the problems as independent issues (Bettencourt \& West, 2010), and it is rare food, water and energy is dealt with together. Each sector generally has its own system, making it difficult to act in a broad and integrated way. When it comes to the environment, some argue that considerable efforts have already been made and that efficient resource use has been achieved so there is little room for further improvements.

Design-led approaches have the potential to break that mold. Design is by its nature a trans-disciplinary approach to problem solving, which draws upon logic, imagination, intuition, and systemic reasoning in order to explore potential innovative solutions to problems (Kimbell, 2011). Designers explore concrete integrations of knowledge that will combine theory with practice for new productive purposes (Buchanan, 2010), integrating the opinions and needs of multiple stakeholders. In spite of the romantic image that design is a highly personal process, in most cases design proposals are in fact the culmination of shared knowledge and consensus on a specific issue (Kimbell, 2012). These advantages make a design-led approach particularly appropriate to addressing wicked problems. The integration of FEW is not yet mainstream. and there is no established design methodology in practice. The nexus approach with regards to FEW in particular was not common in urban planning and design because of the complexity of the problem per se, the uncertainty of outcomes, and the difficulty of communication between scientific research and design as it is practiced.

This article proposes a design-led approach through the concept of the moveable nexus. The goal is to mobilize natural and social resources in urban spaces with integrated technology and knowledge in order to uncover and carry out FEW management innovations. It is also a response to the Sustainable Urban Global Initiative (SUGI) by the Belmont Forum and the Joint Programming Initiative Urban Europe in their call for the FEW-nexus (SUGI, 2016). In their words they ask us "to move stakeholders to action through dialogue from a sector oriented technocratic approach to one that recognizes more diverse viewpoints and rationalities" (SUGI, 2016). The moveable nexus is a methodology that helps designers and practitioners structuring the procedures, knowledge and techniques in design practices with regards to FEW. It is also a moveable platform to deliver the accumulated methods and techniques across cities and countries with regards to practice. We will discuss the essence of the moveable nexus concept, and the planned method for its development through the Belmont Forum joint research project. In Section 2 we will describe the key issues of urban FEW. In Section 3 we look at the components of the moveable nexus. In Section 4 we describe the procedure for implementation, and finally offer preliminary conclusions in Section 5. 


\section{Key Issues in Urban FEW-Nexus}

\subsection{The Challenges to Modern Cities}

Cities are premised upon high population concentrations, accompanied by the conversion of land, originally used for FEW, into industrial activity. The rationality of modern cities was economic efficiency rather than the quality of life. The role of FEW was not diminished in the urbanization process but was dispersed and decentralized. Citizens enjoy greater convenience in daily life, but they become more remote from FEW resources (Loftus, 2009), causing a metabolic rift (McClintock, 2010; SanyéMengual, Anguelovski, Oliver-Solà, Montero, \& Rieradevall, 2016; Tornaghi, 2014). The limits of development and growth become manifest. Increasing climate change disasters and environmental pressures cast shadows on the sustainability of the conventional development model and in many ways force us to look back to basic concepts. Our cities will be not sustainable if we cannot step away from our path dependency in multiple aspects of our urban life (Bai, 2018; Romero-lankao et al., 2017).

\subsubsection{Cities Are Gluttons for Resources}

As an example, depending on the definition of urban areas, about $50 \%$ of the world's urban population consumed two-thirds of the total energy used globally, and are responsible for more than $70 \%$ of energy-related carbon dioxide emissions (Nature, 2010). Estimates of energy consumption by urban buildings and industry range between $37 \%$ and $86 \%$ and estimates of gasoline and diesel consumption attributed to US urban areas range between $37 \%$ and $77 \%$ (Parshall et al., 2010). In most countries, citizens are dedicated to driving, especially those living in suburbia. People rely on cars to meet their basic needs. Families prefer a large house in a new subdivision at the edge of town because they can get there by car. A job across town, remote from where people live and not served by public transit, is just as good as a job nearer to home even if there is a time and financial cost trade-off. Finally, cities become the major driving force to global warming and climate change risks because of the intensity of agglomeration. In light of the recently adopted Paris Agreement on climate change it is necessary to cut global $\mathrm{CO}_{2}$ emissions by $50 \%$ by 2030 , and by $80 \%$ by 2050 , in order to limit global average temperature rising to $2^{\circ} \mathrm{C}$ or less by the end of this century (Rogelj et al., 2016), recently more ambitious to $1.5^{\circ} \mathrm{C}$ (IPCC, 2018). The path towards this goal is clouded but there is no time to wait. Cities, as the most prosperous places on the planet, and as the most intensive contributor to $\mathrm{CO}_{2}$ emissions, will need to play a key role in emission reduction (World Bank, 2018). Viewed from the other side, the high concentration of production and consumption patterns in cities offers opportunities for human society to improve economic efficiency through transformative actions.

\subsubsection{Cities Are Vulnerable}

Our cities, and the systems that support them, have not been designed to address the FEW-nexus. Modern cities were established on a modernist understanding of urban life as an essentialist reality separate from rural life, and urban planning distinctly separated local agricultures as obsolete in a futuristic and normative understanding of the city (Barthel \& Isendahl, 2013). Zoning systems exclude farmland and farming activity in urbanized areas, encouraging land owners to convert their lands to industrial, commercial or residential uses in many cities (Yokohari \& Amati, 2005). Consequently, FEW are transported from distant places, while indicators such as food mileage (Tanaka, 2003), $\mathrm{CO}_{2}$ emissions (Munksgaard, Pedersen, \& Wien, 2000), and virtual water (Allan, 2003a, 2003b) usage steadily rise. Food, water and energy, from production to distribution to consumption and waste treatment are operated by different sectors. Moreover, as currently organized, the relationships between food, water, and energy are not yet mutually beneficial. Instead, they typically exhaust one another. Routinely, urban dwellers are enjoying the conveniences of urban living, and fulfill every need easily, from clothing to food and housing. Superficially, it seems as if FEW can be obtained easily as long as it is paid for. However, accessibility to FEW is in fact dependent on intensive infrastructure, a complicated supply chain of goods, and personal mobility. The intense concentration of populations, consumption activities, critical infrastructures, and social needs in metropolises assume that every part of that infrastructure will continue to work effectively into the future, with very little redundancy (Yan \& Galloway, 2017). That implies that they are more vulnerable to natural hazards than distributed systems (Artioli, Acuto, \& McArthur, 2017; Carpenter et al., 2015).

\subsubsection{Cities Are Tarnishing}

In the last century, in a surge of industrialization and urbanization, massive numbers of people migrated to cities from rural areas in search of a better life. This is now a global and continuing process. However, urban life has not spontaneously improved even as cities grow and their economies thrive. We have witnessed the winners and losers in the past decades of globalization and automatization. A majority of residents suffer from long distance commuting, traffic congestion and heavy workloads in megacities. Slums, crimes and poverty are synonymous in some cities. There is considerable overlap between the 1.1 billion poor people who lack access to adequate water and food, and the 1.5 billion who are without access to electricity (and to some extent the 1 billion slum dwellers in the developing world's cities) (Hoff, 2011). The situation in the so-called developed world is getting worse because of aging and other problems. For instance, the number of people living in food deserts is rising-around one million in the UK (The 
Guardian, 2018), more than 7 million in Japan (Choi \& Suzuki, 2013), and even more in the USA (Walker, Keane, $\&$ Burke, 2010). The cause can generally be attributed to handicaps, unaffordability or aging (Lawson, 2016). This is an entirely new challenge for the provision of quality FEW services in a period of growing inequality.

\subsection{The Essence of Nexus Thinking in Urban Design}

Nowadays, cities are considered places for better life though, as aforementioned, challenges toward sustainability are crucial too. It's true from the global perspective that FEW resources are indispensable for survival, and their conservation and efficient use are necessary for the sustainability of society. However, there exist gaps in awareness of the severity of the issue and the roles of stakeholders at human scales. FEW resources are tangible, and the nexus can be thought to be most inherently visible in nature and in rural communities, simply because the resources are used more directly in both life and work in these locations. Once FEW resources are delivered to cities where they are separated into sectors such as food, water services, electricity, and gas. For urban residents, FEW provides the basis of living, as well as the services provided by governments and businesses. The connection is less immediate, however. Very often, citizens have only been approached as either "receivers" or "users" which implies a passive role. They are not aware of the interrelations of food, water, and energy, and therefore will not change their behavior. To date, most of the FEW researches have been conducted at the macro-level. Accordingly, the urban basis for nexus policy and analysis remains weak (Artioli et al., 2017). Urban plans rarely address the FEW-nexus directly except to assume that continuing access to each aspect will be assured without any special additional measure. Because of this path dependency it can be said that the assessment tools, models, and policy recommendations of many planners seldom build on the nexus of FEW resources. Conventional planning, design, and governance systems struggle to meet the supreme position that cities have taken, namely as the most prosperous places in the modern world.

FEW-nexus thinking provides a tool to rethink the fundamental needs of human society, production and consumption, demand and supply, and cost and benefits etc. Instead of defining FEW as resource security, the FEWnexus in cities should integrate its components into urban space and by doing so, turn the supportive aspect into a mainstream element that could create new opportunities (Kurian \& Ardakanian, 2015). The essence of nexus thinking can be found in three guiding principles (Hoff, 2011):

1. Invest in ecosystem systems to secure FEW provisions;

2. Create more with fewer environmental costs;

3. Ensure accessibility to food, water and energy to all residents.
Implementation of these principles relies on finding solutions to the question: where, how, and who will produce food for cities?

\subsubsection{Where-The Relationship of Production and Consumption}

Typically, modern cities spread over wide areas. Spatially speaking, sustainability research and policymaking should shift focus from city centers to urban regions and global networks of production, consumption and distribution (Powell, 2016). In San Francisco, most of the carbon emissions associated with the consumption of goods by residents, firms and governments in 2008 were created outside the city's limits-elsewhere in the USA or overseas-"yet municipal sustainability initiatives target only the metropolitan area" (Powell, 2016).

Nexus thinking recognizes that production, distribution and consumption crosses both scales and places. The FEW-nexus is nested in multiple spatial scales (Verburg, Mertz, Erb, Haberl, \& Wu, 2013). The extent of the potential of local production for local consumption depends on how and to what extent the distances between production and consumption can be reduced. This does not mean that every place should be self-sufficient and independent. Every city is unique in its land, its people, and its relationships to its ecosystems (Stead \& Pojani, 2018; Thomas et al., 2018). Resources and flows are similarly different in every city and area around the world. Trading is still an efficient way to mobilize local resources and add value to commodities (FAO \& UNEP, 1999). The question is to find an appropriate scale to work at with regards to the provision of FEW to all communities. Depending on location it may be regional or entirely local.

Regarding scale, the singular problem is how to scale up small activities to have large impacts. Various initiatives can be seen around the world that make use of FEW linkages, such as solar sharing, small hydropower generation, local production for local consumption, plant factories, community gardens, urban farming, and so on (Hussey \& Pittock, 2012). Many of these are unsustainable as they are designed for a small number of people or are on a small scale and lack support. A design-led approach leads naturally enough to designed solutions, evaluates marginal benefits, and presents mechanisms that can be used to actualize the ideas. The proposition of the design-led approach is to propel a synchronized outcome, developing symbiotic relationships between FEW. Instead of siloed concepts from production to consumption, stakeholders should emerge as prosumers. These persons and groups collectively will own urban spaces and co-design circular solutions at different urban scales.

\subsubsection{How-The Relationship between Costs and Benefits}

Costs and benefits are the most critical aspects for sustainability. However, this is not an issue of profit or 
costs itself. For instance, car dependent life brings us convenience while causing the bulk of $\mathrm{CO}_{2}$ emissions (Farr, 2012, p. 23). It is a personal lifestyle, and in some ways a representation of moral value (Al-Saidi \& Elagib, 2017). Reducing environmental costs while keeping the same lifestyle requires awareness of and contribution to common values (Ames \& Hershock, 2015), and especially a desire for the sustainability of society. As noted previously the largest portion of $\mathrm{CO}_{2}$ emissions in San Francisco came from food and beverages produced outside the city center, where the consumers actually live (Bettencourt \& West, 2010). Activities for sustainability happen every day and everywhere. Planners make city forms and transportation systems; designers work on buildings; citizens make home gardens; farmers devote to organic farming etc. Some are commercialbased while mostly might be not. Many of them enhance ecosystem services (Costanza et al., 1997) and contribute to shaping a common shared value (Gómez-Baggethun \& Barton, 2013; Haase et al., 2014; Tratalos, Fuller, Warren, Davies, \& Gaston, 2007). These values are not always clear to the people themselves, as it is a collective creation, made by local decisions. How to include new practices in planning and design so the quality and benefits can be expressed clearly (and visually) to all of residents of a city remains an unsatisfied challenge.

For urban residents, on the other hand, FEW themes appear as (private or public) services of the social infrastructure. Citizens seldom see the hidden sides of the workings of government or businesses. People generally tend to be most strongly interested in daily life and work issues affecting their own families, neighborhoods, cities and regions, and have less interest in things that are not short-term or connected to their own immediate benefit. In fact, most modern cities were established on centralized energy, water supply and treatment systems, and the maintenance of the infrastructure involves enormous costs. Consumers are usually not able to get the direct experience of FEW resources being physically interconnected. This leads to severe constraints for integrated urban FEW designs, especially in cities with high disaster risks, and drastic demographic or industrial shrinkage.

The second principle of nexus thinking is to create more with less. We do not yet know how easy or difficult it is to replace centralized infrastructure with small scale distributed systems. Smart cities and smart communities are popularly experimented with (City of Chicago, 2009; Gondhalekar \& Ramsauer, 2017; Townsend, 2013; Wolsink, 2012) and may eventually lead to useful conclusions, but that time is still somewhere in the future. Most of the tests are technology-oriented, and focus on energy (Wongbumru \& Bart, 2014). Some look to water (Venkatesh, Chan, \& Bratteb $\varnothing, 2014$ ), and few focuses on food or FEW-nexus themes (Gondhalekar \& Ramsauer, 2017; Wolsink, 2012). To go further we will need a mechanism to ensure the natural costs are paid and to ensure that choices are beneficial to both ecosystems and human beings, individuals and businesses. The nexus ap- proach tries to establish such a win-win approach in which urban resilience, citizens' health and accesebility to resources could be shaped as the common value outpacing the costs.

\subsubsection{Who-Relationship between Working and Living}

With the Industrial Revolution, the main source of wealth moved from the countryside into the city (Cusinato, 2016). Urban living has served as a symbol of material wealth so that younger people continuously migrate from the countryside, especially in developing countries (The Economist, 2011). In fact, the wealth of modern cities was built on the marginal effect of cheap labor forces and external costs to the environment. In many cities around the world, and especially in the West, cities have been designed according to a zoning plan that separates working and living places in order to preserve efficiency of land use. FEW systems under this regime are centralized and work at large scales. However, this established working-living style is collapsing because of globalization and automatization. Factories are moving away from expensive cities where there are cheaper natural and human resources, leaving polluted vacant land behind, as in the cases of Belfast or Detroit. New business may continuously emerge in place of the old but there is a tendency to require a different kind of worker, if not an outright reduction in the number of people needed for the enterprise. What can be done in a city without jobs? What to do with massive numbers of vacant houses, void lands, and decayed infrastructure in an aging and shrinking society (Thieme \& Kovacs, 2015)? FEW offers some thoughts. For instance, feeding the city through urban agriculture has been widely discussed (Moreno-Peñaranda, 2011; Morgan, 2009; Mougeot, 2000; Tornaghi, 2014), and practiced popularly from rooftops (Engelhard, 2010; Whittinghill \& Rowe, 2012), home gardens (Barthel \& Isendahl, 2013), formal landscapes (Bohn \& Viljoen, 2011) and shared farmland in peri-urban areas (Hara, Mcphearson, Sampei, \& Mcgrath, 2018; Meeus \& Gulinck, 2008; Mok et al., 2014). It is too much to say that urban farming will solve the problem of job migration that has taken place as a result of globalization, however it is not impossible that the use of FEW-nexus planning could set the stage for an alternative form of future urbanism, where work and life are more closely inter-related, along with FEW production and use.

Taking this idea further, urban sustainability can be understood not merely an issue of environmental conservation but the future of urbanism and urbanized civilization. Cities, as the dominant settlements, the home of most people on this planet, should not only be a place for work but also for living and fulfillment. FEW, both as a fundamental demand and as an infrastructure, could be not only the provisioning service but also a carrier of social ecological memories in cities even by practicing FEW nearby small scales (Andersson \& Barthel, 2016; 
von Heland, 2011). Mobilizing the related FEW potentials could work as a trigger for urban regeneration, wealth redistribution and the improvement of well-being. The design-led nexus approach will integrate the nexus principles with urbanism, such as producing local consuming local in practice. Following on that work, design solutions will be transferred to action programs for the UN Sustainable Development Goals (SDGs) with the cooperation of producers that aim for the balance of beneficial economic effects and environment, citizens in search of a better living environment, and governments that seek to provide efficient public services.

\section{Design-Led Nexus Approach}

The design-led approach aims to develop FEW solutions in cities to mobilize the potential of natural resources at multiple scales, improving the efficiency of land and resources, delivering services to all who require it. There is no such thing as a one-size-fits-all solution to any problem amidst the diversity of local and global contexts. Therefore, design itself should be a process of learning, integration and communication. The moveable nexus is such a concept within this philosophy.

\subsection{The Concept of the Moveable Nexus}

Research and design practice on food, water, and energy by sector are not new. Rich knowledge is accumulated in each discipline. A huge amount of research has been conducted on the nexus-pairs of food-energy (FE), energy-water (EW; IRENA, 2015; Varbanov, 2014) and food-water (FW; White et al., 2015), climatic impacts (Carpenter et al., 2015; Johansson, Schmid Neset, \& Linnér, 2010; White et al., 2015) or the three pillars of FEW (Endo \& Oh, 2018; Endo, Tsurita, Burnett, \& Orencio, 2014).

While nexus literature is long on determination and ambition, it is short on grounded evidence on the essential elements of FEW security, such as operational definitions that help to link research and practice, particularly within urban systems. (Romero-lankao \& Gnatz, 2016)

Most of the previous studies view FEW issues from the supply side of resources, investigating the scientific mechanisms of material flows, predicting the increase of FEW risks associated with population growth and development. Typical examples include the survey of ecological resource availability (Daher \& Mohtar, 2015), urban metabolism modeling of production, consumption and disposal (Bazilian et al., 2011), shifting to a lowcarbon circular economy (Bears, 2017; Bhaduri, Ringler, Dombrowski, Mohtar, \& Scheumann, 2015), and reducing external inputs from outside the region while encouraging local production for local consumption (Siddiqi \& Anadon, 2011). However, scientific knowledge is not popularly applied in many of the design practices linked to the creation of the built world. Similarly, with some notable exceptions such as the Living Building Challenge, architects design buildings to save and manage energy, or work on the redevelopment of urban neighborhoods to improve livability. Landscape architects work on urban landscapes, urban agriculture and green infrastructure to create the feeling of a greener urban life. City planners study land use policy to improve efficiency of transportation and distribution. Quite often, participatory design in the literature is introduced as a kind of event-driven professional and educational activity, lacking the ability to transfer the gained knowledge to a large scale of practice. With regards to the FEW-nexus, each profession has a kind of limitation of scope that needs to be bridged both in breadth and in scale.

The moveable nexus is considered as an innovative methodological package for FEW management and utilization that make use of the spatial, temporal, and service linkages of natural and social resources. As the illustration in Figure 1, the package offers an indication as to how to practice nexus thinking in a way that will lead to its integration with urban planning, architectural design, and environmental policy studies. Ultimately it is a communication platform that can be moved to a design site with the support of scientific data and knowledge.

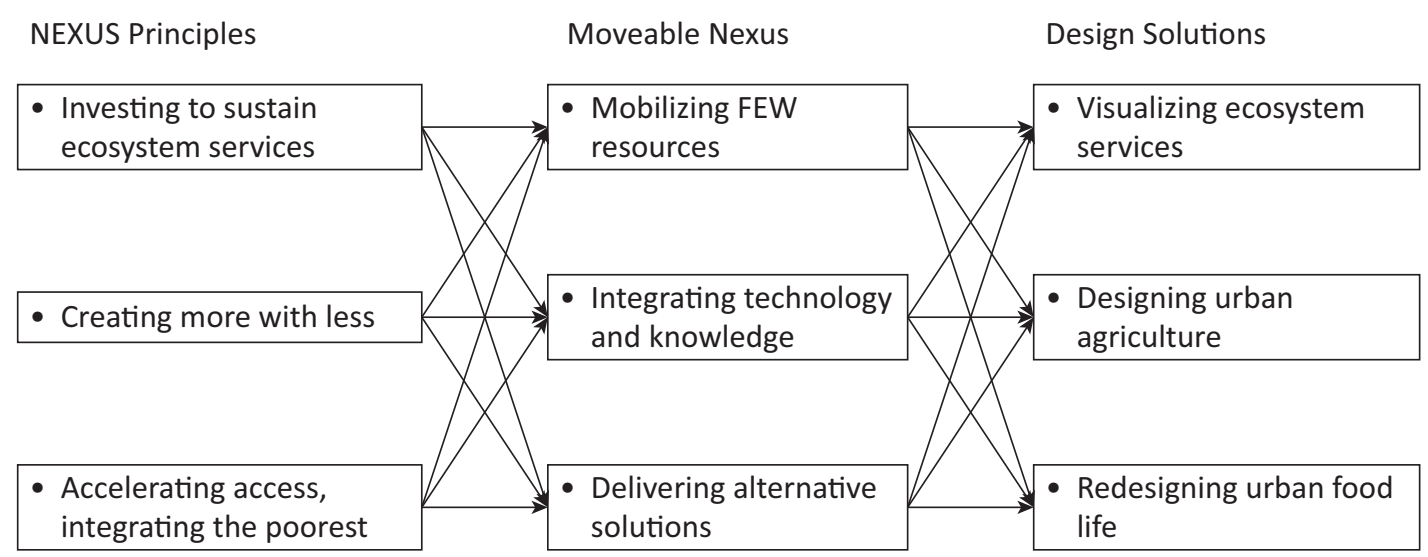

Figure 1. Principle of nexus thinking and moveable nexus. Source: authors. 


\subsection{The Development of the Moveable Nexus}

The moveable nexus consists of design methods, evaluation tools, and participation mechanisms that can be used in design practice. The guiding principles for the development are described below.

\subsubsection{Design Methods}

The application of FEW-nexus and urban agriculture in cities could take a diversity of forms, including technology or policy, buildings or landscape, commercial products or public engagement programs. Design methods at the moveable nexus provide guiding procedures to explore solutions with stakeholders. The procedures of the design method construction consist, in general, of the following steps, as shown in Figure 2:

1. Inventorying FEW-related existing or potential resources and availability of space for urban agriculture, including rooftops, vacant houses, or abandoned, improperly used or void lands;

2. Designing solutions to improve the efficiency of land and space use for food production and ecosystem services with less energy and water consumption by integration of FEW technology and knowledge;

3. Composing the nexus matrices that mobilize the material and flows of resources cross sectors and disciplines in the social-ecological context;
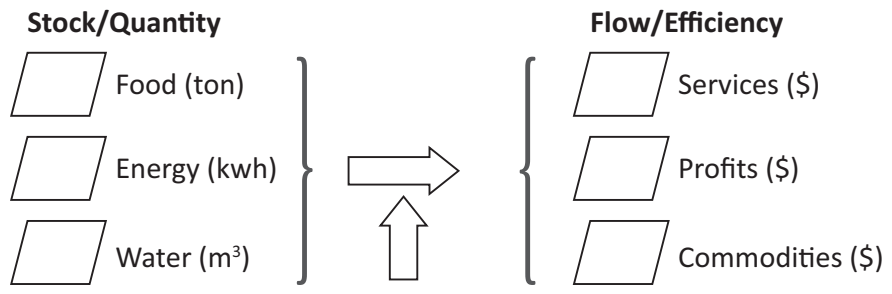

Design

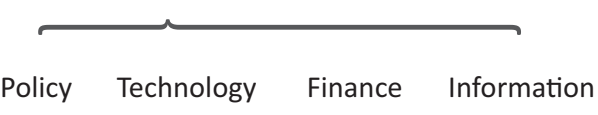

Innovation

Creating more with less
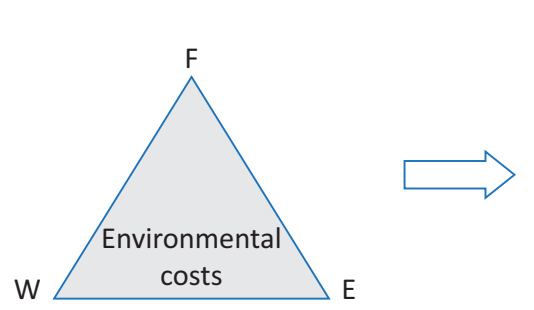

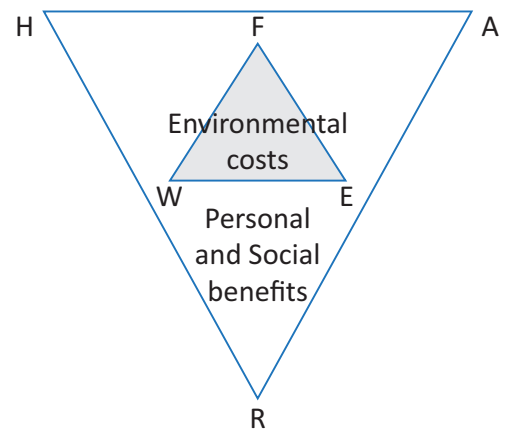

4. Evaluating the environmental costs and the added benefits of the solutions through the enhancement of spatial, temporal and service connections among specific social-ecological systems;

5. Delivering the alternatives of solutions to and reiterate the design process with stakeholders.

This is co-design and a reflexive process with stakeholders. The inventory includes natural, social, financial, and industrial aspects. The mobilization of resources implies the activation and connection of existing and potential capitals across industrial, administrative and academic boundaries with more flows and services.

\subsubsection{Evaluation Tools}

The evaluation of design solutions is a tricky issue. There exists a long list of indicators to assess the impact of human activities on the environment, such as the most typical ones, food mileage (f), $\mathrm{CO}_{2}$ emissions (e), virtual water use (w), Ecological Footprint (EF), etc. However, no such an indicator could properly describe the interaction of FEW.

EF (Wackernagel \& Rees, 1998) converts the $\mathrm{CO}_{2}$ emission in human consumption to land area equivalent to the area of forest demanded for absorbing the correspondent emission. We propose an indicator fewprint which express the quantity of FEW resources to be consumed and the flow-that is, the service-among the three layers. The few-print is a combination of food

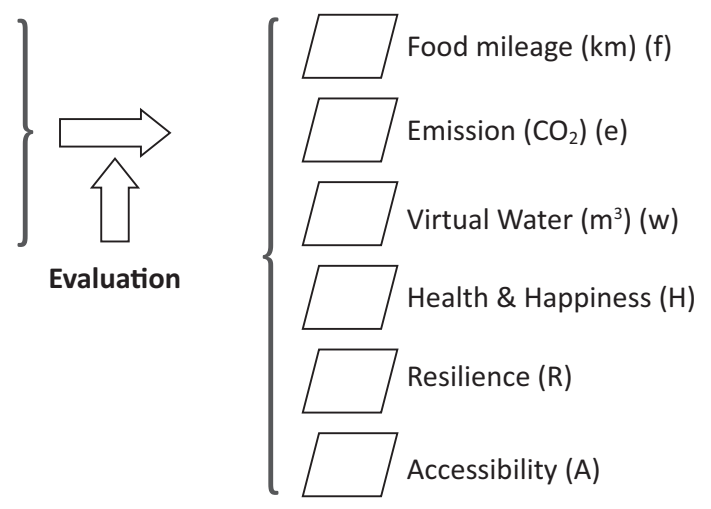

Solutions (samples)

- Local production local consumption

- Food products

- Rooftop gardening

- Urban farming

- Food market and food service

- FEW infrastructure

Figure 2. Framework of the moveable nexus. Source: authors. 
mileage (f), $\mathrm{CO}_{2}$ emissions (e), virtual water use (w). It also represents the ambition of nexus thinking: creating more with less.

On the other hand, the functions of urban agriculture are multifaced. People enjoy home gardens or shared farming not necessarily for the $\mathrm{CO}_{2}$ reduction but rather for other benefits, such as education, health, culture and communication etc. Similarly, some new issues can emerge from the process, such as a reduced few-print that goes along with reduced accessibility to those resources by the residents of an area. Investors might also pursue common shared values with the public on urban agriculture and ecosystem services rather than on food production itself. Therefore, in addition to few-print, we incorporate three social indicators in perspective of citizens' quality of life: health and happiness $(H)$, accessibility $(A)$ and resilience (R), collectively referred to as HAR. Although each indicator has been intensively studied (for health and happiness see Groenfeldt, 2006; Urban Nexus, 2013a; for accessibility see Walker et al., 2010; for resilience see Magis, 2010; Mitchell, \& Harris, 2012) the trade-offs and synergistic effects with environmental factors have not been examined.

The development of the few-print and HAR is a complex process in design. The numbers might mean different things as scales change from household, to city block to neighborhood, to the city and bioregion. The indicators of the moveable nexus in this way may not be perfect tools to judge the quality of solutions but more appropriate for communication. Stakeholders will need to understand the trade-off and synergy of different solutions at different scales so that each partner could rethink the relationships about costs and benefits, and their behavior.

\subsubsection{Participation Mechanisms}

Involving users in urban design and development has long been a core concept though practice is often different between social contexts (Bergvall-Kåreborn, Howcroft, Ståhlbröst, \& Melander, 2010). "Through engagement with a product or service over time and space", Kimbell (2012) says, "the user or stakeholder continues to be involved in constituting what a design becomes". Designers explore concrete integrations of knowledge that will combine theory with practice for new productive purposes (Buchanan, 2010). "Design with users, design by users or design for users are popularly advocated within areas like innovation and product development" (Bjögvinsson, Ehn, \& Hillgren, 2012; Wahl \& Baxter, 2008). However, how to sustainably involve stakeholders especially over the long term is not easy for any participatory project. There are examples, however, that tend to be self-selecting groups who have bought into a larger goal. The community involvement of residents in Freiburg, who collectively built their eco town over decades. People who move to Freiburg did so in order to be part of that process (Freiburg, 2018). Bringing otherwise regular people into design is a more challenging task.
In the moveable nexus, the participatory mechanisms are the collaboration process of four type of partners: intermediate support organizations, the local community, experts in spatial planning, and public or private sectors. Each partner owes specific resources and advantages such as physical spaces, skills, knowledge, financial or regulative options. Our understanding is that intermediate support organisations, mostly driven by local actors, play a key role to connect stakeholders together.

The engagement of the multiple stakeholders is conducted through a series of design workshops in the moveable nexus. All of the stakeholders incorporate equity into every stage of design process, from research to formulation (Powell, 2016). During the workshop, design experts visualize resources and produce solutions. Local community gain awareness of the issues and co-create the shared values. Private or public sectors could be inspired and then turn the plan and design into political and business actions.

The design workshops will be informed with scientific evidence. The moveable nexus provides a platform for communication and learning of stakeholders, in which the FEW resources and evaluation indicators aforementioned are installed. As the results, the design solutions incorporate the wishes and intentions of all of the participants and then fits a variety of action plans and projects, while enriching the physical and social resources that are unique to the region.

Finally, the moveable nexus itself is co-developed incrementally with stakeholders through the processes in practice. Urban Living Labs (ULLs) are used as a platform to implement/accommodate the contents of the moveable nexus and secure the sustainability of the practice.

\subsection{Urban Living Lab for Practice}

ULLs are initiatives that focus on the collaboration of multiple stakeholders (government, industry, research institutions and communities) in different stages of the research, development and innovation process (Thinyane, Terzoli, Thinyane, Hansen, \& Gumbo, 2012). It is also a recommendation of funding agencies such as JPI Europe Urban. Over the decades, the concept of living labs has become widely accepted in design practice with design thinking and system thinking (Kimbell, 2011), shifting design from design "things" to design "Things" (Bjögvinsson et al., 2012). Compared with regards to its popularity to open innovation, lead users, public health, IT tools, user-driven design (Bergvall-Kåreborn, Holst, \& Ståhlbröst, 2009), it has only a limited success. Voytenko, McCormick, Evans and Schliwa (2016) surveyed five living lab projects granted by JPI Europe Urban and concluded that the concept was mostly used to secure funding. There remain many questions about the impacts and effectiveness of ULLs both in their own geographical domain and more broadly at regional and national scales. For example, how do ULLs evaluate their own impacts? How do they build on feedback results and findings of 
evaluation to improve their activities and impacts? These questions are reminiscent of the problems outlined in Section 2. Researchers, designers and stakeholders have difficulties in communication with each other because of the gaps between scientists and citizens, long-term global goals and the short-term personal interests on sustainable issues as well as FEW issues. Answering the questions need a collaboration network working on common issues with a designated scheme.

The moveable nexus by its nature requires the bioregion-specific collaboration of stakeholders. On the other hands, the methodology and platform of the moveable nexus could be applied everywhere for the researcher, designers and practitioner who share common understanding. An ULL could be an existing one run by cooperative stakeholders or a new one initiated by researchers. With the support of a living lab, researchers could work strategically with stakeholders to co-design long-term strategies for urban productivity in light of changing contexts. The living labs created in research areas could be part of a global network for comparative studies.

Therefore, the moveable nexus and ULLs are complementary ideas each other. The former provides contents while the latter has advantages of practical platforms with stakeholders. The moveable nexus could also help ULL to move around with the shared contents, thereby enabling global deployment. In this sense, the moveable nexus could add new values to ULLs with integrated solutions for urban FEW managements.

\section{Implementation}

\subsection{Research Sites}

The moveable nexus was proposed as the core concept of the project "The Moveable Nexus: Design-Led Urban Food-Energy-Water Management Innovations in New Boundary Condition of Change" (M-NEX) granted by Belmont Forum and JPI Europe Urban. The purpose of the project is to show how topics and issues of FEW that span across diverse regions in the world can be studied within a uniform concept. A research consortium with seven organizations in six countries (Australia, Japan, the Netherlands, Qatar, UK, USA) has been established, with its study areas being Sydney, Tokyo-Yokohama, Amsterdam, Doha, Belfast, Detroit correspondently.

The geographical features, bioregional differences and social themes of every study area are summarized in Table 1. The cities differ in terms of geographical features, bioregions and societal conditions, but from the table it is clear all cities are mature and share several common concerns in terms of sustainability in their urban areas. The project will take the complex sustainability challenges of its involved cities, and communicate FEW design solutions in concrete, visual, and physical ways to stakeholders and residents. This will deepen the understanding of FEW and promote consensus-building on actions plans for future cities.
Each country team will determine the research contents in consideration of the local needs and proceed collaboratively. For example, the UK team (Belfast) will work on design of food factories, while the Dutch team (TUD) will focus on energy planning in FEW-nexus. All of the teams will learn from each other and study the potential to incorporate FEW-management into their own cities. Ultimately, they will deliver their research findings, policy recommendations and technical innovations, such as implementation of FEW at a University campus (Doha), revitalization of a post-industrial city (Detroit), and future FEW strategies for consumption-oriented cities (TokyoYokohama, Sydney).

\subsection{Working with ULLs}

Each team builds an ULL in the study area, hold stakeholder and community design workshops, consider local FEW-topics, and develop solutions. The ULL in each city is featured with the local social and bioregional context.

\subsubsection{Belfast}

Northern Ireland has generally weak infrastructure and a very poor natural gas network due to the recent civil strife known as 'the Troubles'. In supply side of food, a strong reliance on imported food due to heavily industrialized and dense beef and dairy farming, very little arable agriculture. On the other hands, a strong dependence on the car due to poor public transportation in conjunction with poor diets due to food poverty, leads to increasingly prevalent issues surrounding obesity and diabetes. The Belfast Living Lab is based in the designated Urban Villages project. This project funded by the Northern Ireland Assembly works in 5 of the most deprived neighborhoods in Northern Ireland, to facilitate sustainable development of these at risky groups.

\subsubsection{Tokyo}

The 2011 earthquake and tsunami in Tohoku revealed the vulnerability of modern cities. Many areas in Japanese cities were built in the twentieth-century postwar period of high economic growth and are now approaching a time when infrastructure and other upgrades will be needed. Japanese cities are also facing declining birthrates and aging of the population and becoming more compact, even as they face rapid changes on the spatial and temporal dimensions in terms of the supply and demand for FEW (Moreno-Peñaranda, 2011). The Tokyo Living Lab is going to work in cooperation with WISE Living Lab, a community-based project initiated by Yokohama City and Tokyu Corporation since 2012 in which WISE represents an acronym of Wellness; Intelligent and ICT (Information and Communication Technology); Sustainable and smart; and Ecology, energy, economy. In the summer of 2018 the Japanese government selected 29 municipalities as pilot SDGs model 
Table 1. Overview of characteristics of partner cities and case study projects.

\begin{tabular}{|c|c|c|c|c|c|c|}
\hline $\begin{array}{l}\text { Partner } \\
\text { City }\end{array}$ & $\begin{array}{l}\text { Belfast } \\
\text { (BEL) }\end{array}$ & $\begin{array}{l}\text { Doha } \\
\text { (DOH) }\end{array}$ & $\begin{array}{l}\text { Detroit } \\
\text { (DET) }\end{array}$ & $\begin{array}{l}\text { Sydney } \\
\text { (SYD) }\end{array}$ & $\begin{array}{l}\text { Tokyo } \\
\text { (TOK) }\end{array}$ & $\begin{array}{l}\text { Amsterdam } \\
\text { (AMS) }\end{array}$ \\
\hline $\begin{array}{l}\text { Main } \\
\text { thematic }\end{array}$ & Divided city & Food security & $\begin{array}{l}\text { Vacancy and } \\
\text { Capacity } \\
\text { building }\end{array}$ & $\begin{array}{l}\text { Urban } \\
\text { Development } \\
\text { process }\end{array}$ & $\begin{array}{l}\text { Ageing and } \\
\text { disaster risk }\end{array}$ & $\begin{array}{l}\text { Co-creation } \\
\text { of spatial }\end{array}$ \\
\hline Climate & Maritime & Desert & Continental & Subtropical & Subtropical & Maritime \\
\hline Bioregion & $\begin{array}{l}\text { Northern } \\
\text { Ireland } \\
\text { Bioregion }\end{array}$ & $\begin{array}{l}\text { Arabian } \\
\text { Desert } \\
\text { Bioregion }\end{array}$ & $\begin{array}{l}\text { Great Lakes } \\
\text { Basin Bioregion }\end{array}$ & $\begin{array}{l}\text { Sydney Basin } \\
\text { Bioregion }\end{array}$ & $\begin{array}{l}\text { Kanto Plain } \\
\text { Bioregion }\end{array}$ & $\begin{array}{l}\text { Atlantic Mixed } \\
\text { Forest } \\
\text { Bioregion }\end{array}$ \\
\hline Scale & Neighbourhood & $\begin{array}{l}\text { Precinct: } \\
\text { Uni-campus }\end{array}$ & $\begin{array}{l}\text { Metropolitan } \\
\text { region }\end{array}$ & $\begin{array}{l}\text { Large } \\
\text { Greenfield: } \\
\text { 3rd City }\end{array}$ & $\begin{array}{l}\text { Roof / } \\
\text { vacant land }\end{array}$ & Neighbourhood \\
\hline FEW-focus & $\begin{array}{l}\text { F: Diet } \\
\text { E: Algae } \\
\text { W: Flood }\end{array}$ & $\begin{array}{l}\text { F: Local } \\
\text { plantation } \\
\text { lowering UHI } \\
\text { E: Solar } \\
\text { W: Drought, } \\
\text { reuse }\end{array}$ & $\begin{array}{l}\text { F: Urban } \\
\text { production } \\
\text { E: Waste to } \\
\text { energy } \\
\text { W: Great } \\
\text { Lakes Basin }\end{array}$ & $\begin{array}{l}\text { F: Regional } \\
\text { food-bowl } \\
\text { E: Large and } \\
\text { small hydro } \\
\text { W: Heat }\end{array}$ & $\begin{array}{l}\text { F: Food in } \\
\text { urban roof / } \\
\text { rural } \\
\text { E: Solar panel } \\
\text { W: Water-river } \\
\text { basin }\end{array}$ & $\begin{array}{l}\text { F: High tech, } \\
\text { vertical } \\
\text { E: Wind \& } \\
\text { integrated } \\
\text { renewables } \\
\text { W: flood, } \\
\text { controlled }\end{array}$ \\
\hline Motto & $\begin{array}{l}\text { 'The Aquaponic } \\
\text { city' }\end{array}$ & $\begin{array}{l}\text { 'The urban } \\
\text { water machine' }\end{array}$ & $\begin{array}{l}\text { 'The post- } \\
\text { industrial city' }\end{array}$ & $\begin{array}{l}\text { 'The fridge } \\
\text { city' }\end{array}$ & 'WISE city' & $\begin{array}{l}\text { 'The circular } \\
\text { city' }\end{array}$ \\
\hline Take away & Technologies & $\begin{array}{l}\text { People } \\
\text { Engagement }\end{array}$ & $\begin{array}{l}\text { Regional } \\
\text { synergies } \\
\text { Scalar } \\
\text { Cascades }\end{array}$ & $\begin{array}{l}\text { Far future } \\
\text { design }\end{array}$ & $\begin{array}{l}\text { Regional } \\
\text { integration }\end{array}$ & $\begin{array}{l}\text { Design with } \\
\text { flows for far } \\
\text { future }\end{array}$ \\
\hline Goal & $\begin{array}{l}\text { Existing } \\
\text { technologies } \\
\text { in the city }\end{array}$ & $\begin{array}{l}\text { Expanding the } \\
\text { effectiveness } \\
\text { of food } \\
\text { production in } \\
\text { the city with } \\
\text { minimal water } \\
\text { availability }\end{array}$ & $\begin{array}{l}\text { How to } \\
\text { overcome } \\
\text { jurisdictional } \\
\text { barriers }\end{array}$ & $\begin{array}{l}\text { Using } \\
\text { landscape as } \\
\text { cooling } \\
\text { machine } \\
\text { through } \\
\text { plantation, } \\
\text { crops and } \\
\text { water }\end{array}$ & $\begin{array}{l}\text { Close FEW } \\
\text { cycles at river } \\
\text { basin level }\end{array}$ & $\begin{array}{l}\text { Close FEW } \\
\text { cycles at city } \\
\text { level }\end{array}$ \\
\hline Data & Baseline data & $\begin{array}{l}\text { Place based } \\
\text { data (QU } \\
\text { campus) }\end{array}$ & $\begin{array}{l}\text { Regional } \\
\text { jurisdictional } \\
\text { data }\end{array}$ & $\begin{array}{l}\text { Regional } \\
\text { landscape } \\
\text { data }\end{array}$ & $\begin{array}{l}\text { Building and } \\
\text { land use data }\end{array}$ & $\begin{array}{l}\text { Flows of FEW } \\
\text { data }\end{array}$ \\
\hline $\begin{array}{l}\text { Method for } \\
\text { workshop }\end{array}$ & Roadshow & $\begin{array}{l}\text { Design } \\
\text { workshop }\end{array}$ & $\begin{array}{l}\text { Large scale } \\
\text { spatial drawing }\end{array}$ & $\begin{array}{l}\text { Creative } \\
\text { COCD }\end{array}$ & $\begin{array}{l}\text { GIS } \\
\text { modelling }\end{array}$ & $\begin{array}{l}\text { Stakeholder } \\
\text { co-design }\end{array}$ \\
\hline $\begin{array}{l}\text { Paradigm } \\
\text { shifts }\end{array}$ & $2050-2080$ & $2050-2100$ & $2035-2070$ & $2030-2060$ & 2040-2080 & 2040-2070 \\
\hline \multirow[t]{2}{*}{ Outputs } & $\begin{array}{l}\text { Part I of } \\
\text { few-print }\end{array}$ & $\begin{array}{l}\text { Part II of } \\
\text { few-print }\end{array}$ & $\begin{array}{l}\text { Part III of } \\
\text { few-print }\end{array}$ & $\begin{array}{l}\text { Part IV of } \\
\text { few-print }\end{array}$ & $\begin{array}{l}\text { Part V of } \\
\text { few-print }\end{array}$ & $\begin{array}{l}\text { Part VI of } \\
\text { few-print }\end{array}$ \\
\hline & $\begin{array}{l}\text { Advanced FEW } \\
\text { Technologies } \\
\text { in the city into } \\
\text { the future }\end{array}$ & $\begin{array}{l}\text { Community } \\
\text { gardens and } \\
\text { permaculture, } \\
\text { for higher } \\
\text { scales }\end{array}$ & $\begin{array}{l}\text { Jurisdictional } \\
\text { system, } \\
\text { Visualizing } \\
\text { Cascading } \\
\text { systems and } \\
\text { scales }\end{array}$ & $\begin{array}{l}\text { FEW-urban } \\
\text { landscapes }\end{array}$ & $\begin{array}{l}\text { FEW- } \\
\text { integration } \\
\text { in local } \\
\text { community }\end{array}$ & $\begin{array}{l}\text { Energy } \\
\text { cascading / } \\
\text { REAP for Food } \\
\text { and Water }\end{array}$ \\
\hline
\end{tabular}


projects including Yokohama City, started to tackle these issues (Cabinet, 2018). The M-NEX Japan Team is designing new management systems to secure the accessibility of urban FEW in the Tokyo-Yokohama metropolitan area plus sustainable improvements in the quality of life, and the necessary infrastructure to support all of that.

\subsubsection{Sydney}

It is foreseen the Sydney region will be confronted with a rapid increase in population in the next $20-30$ years (Greater Sydney Commission, 2018). The number of people will almost double and reach a total of approximately 8 million people. To cope with this enormous change the regional planning authority (Greater Sydney Commission) has presented the region as a metropolis of three cities: the old Harbour city in the East, the central Parramatta river city and the newly to be developed Western Parkland city around the new Badgerys Creek airport (Greater Sydney Commission, 2018). The Sydney Living Lab will be the new Western Parkland City, around the new Airport of Badgerys Creek. The task is to explore what new type of city could emerge here, given the fact that current development processes often not lead to a very smart, resilient and sustainable outcomes, as these neighborhoods tend to have sparse green and trees, maximized housing space on plots, people commuting to the city and spend large amount on energy because of the need of air conditioners.

\subsubsection{Doha}

Qatar has limited water resources; the climate is too hot and dry for much agriculture; dust storms are a serious threat. It has the highest per capita emissions of carbon dioxide in the world because of free electricity and the reliance on energy-intensive desalination for potable water. Qatar is extremely vulnerable to rising sea levels and rising temperatures due to climate change. A recent embargo by neighboring states including Saudi Arabia, a major food supplier of Qatar, has heightened the necessity for more efficient and resilient food systems and supplies. The Doha Living Lab will be built on the existing Edible and Regenerative Campus project as well as on ongoing research and networks at Qatar University related to the FEW-nexus such as new food crops, halophytes and micro algae and reuse of water, etc., under the theme of the "The Urban Water Machine" with the engagement of all the University communities.

\subsubsection{Detroit}

Referred to globally as an example of post-industrial shrinking cities, Detroit has suffered from chronic socioeconomic and race segregation coupled with income inequality that amplified de-population of the central city. The urban footprint of Detroit is vast $\left(143 \mathrm{mi}^{2}\right)$ in area and designed in parallel with the emergence of the auto- mobile and models of single-family car ownership. Currently $22 \mathrm{mi}^{2}$ acres of vacant residential and commercial land within the municipal limits. Extensive area of land is characterized as brownfields. While USDA (United States Department of Agriculture) metrics for food deserts point to a crisis of food access within Detroit, multiple alternative sources are emerging within the urban agricultural space. Community, NGO and larger organizations are undertaking urban agriculture practices and food hub production is increasing. This context is ripe for FEWnexus based analysis. Which may assist stakeholders in catalyzing change while identifying multiple collateral benefits to water and biomass-linked processing practices. The M-NEX Detroit will work with the U-M Detroit Center as a Living Lab partner. Located in the heart of the city's Cultural Center, the U-M Detroit Center serves as a gateway for University and urban communities to utilize each other's learning, research and cultural activities.

\subsubsection{Amsterdam}

Amsterdam is dealing with climate adaptation issues and with the ambition to become climate neutral by 2050 , as well as natural gas free. The city is still strongly reliant on food supply from elsewhere, as only a small share comes from the region. Schiphol Airport is a collection point of waste (food, water, materials), which is treated or incinerated elsewhere, far away. The Amsterdam Institute for Advanced Metropolitan Solutions (AMS) has The Circular City as one of their three key themes. AMS, an institute by TU Delft, Wageningen University and MIT, collaborates with the City of Amsterdam and local stakeholders, using the city as living lab for the transition to a sustainable future. The M-NEX Amsterdam is going to work in cooperation with the AMS Institute, the Amsterdam Institute for AMS. The M-NEX Living Lab will be selected and elaborated with AMS Institute and the City of Amsterdam, involving stakeholders from the city, public, private and individual to work together.

\subsection{The Collaborative Scheme}

The moveable nexus shall be developed incrementally through a series of design workshops at the above six living labs with all of the partners (see Figure 3 ). The project engagement will consist of six stakeholder workshops, one in each living lab that engage with key aspects of the FEW, in a bioregional context. This international workshop coincides with one of the (six) participatory workshops in each city. The international team will participate in this workshop and bring their particular skills and knowledge to it. Each of these international workshops has their own focus. The first workshop in Belfast (BEL) focuses on the creating an Initial vision on the technical food systems and the city. In the second workshop in Doha (DOH) the focus is on the city farm, stakeholder participation and urban agriculture. Workshop three (Detroit, DET) focuses on climate futures, de- 


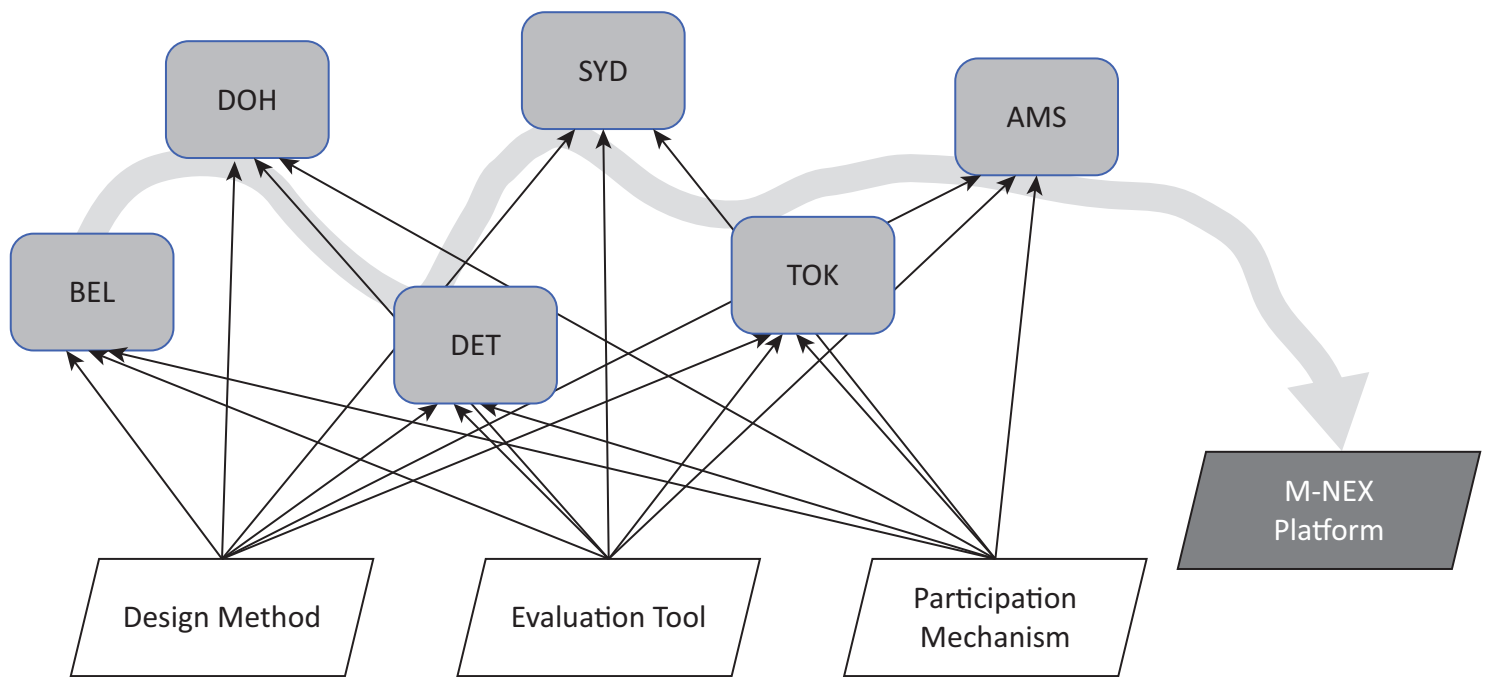

Figure 3. Scheme for the implementation of the moveable nexus.

velopment of regional scenarios and resilience in light of a changing climate. Workshop four (Sydney, SYD) focuses on building Integration, integrating FEW-technologies at user scale. Workshop five (Tokyo, TOK) focuses on stocks and flows for regional planning and the nested neighborhood. And the final workshop (Amsterdam, AMS) focuses on implementation, from strategy to tactics. Each team will bring its own topics to the international design workshop, and the teams together will refine them and build common design methods, evaluation indicators, and co-creation mechanisms. The teams will bring what they have learned back to their countries, put them into practice in their local Living Labs and undertake action toward the next international workshop. Finally, the knowledge obtained at each workshop will be integrated and provided as expertise and solutions from the M-NEX Project at each level, from building to neighborhood, city, and region.

\section{Conclusions}

The fact that environmental issues are indeed global in nature, gives reason to international collaborative research. Meanwhile, environmental problems are complex and require interdisciplinary efforts. With this awareness, the nexus approach is increasingly important. An enormous amount of effort is needed to create multinational and multi-sectoral research frameworks. Key issues to establish real integrative plans, projects and programs are the use of design-led methods and approaches, the implementation of early assessments, e.g., during the planning process and not afterwards, and finally the early, e.g., from the beginning, co-creative involvement of stakeholders and citizens in the planning and design phase of projects. The essence of the moveable nexus, the design-led approach is to facilitate the further integration of FEW in cities in an accessible way. Design is appealing to many and makes it possible to visualize solutions and possible outcomes of the benefits of each FEW-part being each other's resource and service, so everyone can understand these abstract relationships hence be involved. It also makes it possible to assess the propositions at a very early stage, and this holds the opportunity to amend projects during the planning stage rather than after realization. Huge costs can be prevented.

The moveable nexus is defined with three meanings correspondent to the nexus thinking and the SUGI call:

1. To mobilize social and natural resources to create more with less for all the needed with design solutions;

2. To move stakeholders to action through cross sectoral dialogue with informed platform of M-NEX;

3. To move around local and global to the needed with the support of guiding principles and informed platforms.

Unlike the conventional approaches of research and practice, which try to deliver established knowledge and tools to users, the construction of the moveable nexus itself is through a series of design workshops which are open to any stakeholders. The three components of the moveable nexus shall be developed reflexively through engagement of stakeholders. The open idea has much adaptivity and applicability to diverse contexts while we should also keep mind the challenges in practices crossing cities (Stead, 2012; Stead \& Pojani, 2018).

The concept of the moveable platform, the incremental development process, and the participatory workshops in a row are flexible to different research sites. It shares similar concept with urban living labs while the former focuses on contents and the latter has advantage of participatory platform. The collaboration of these approaches will create synergetic effects and demonstrate solutions for urban sustainability. 


\section{Acknowledgements}

M-NEX is a granted project of Collaborative Research Area Belmont Forum (no. 11314551) led by Wanglin Yan (Keio University) in consortium with partners from Japan, including Keio University and Institute for Global Environmental Strategies, Qatar, led by Kas Oosterhuis at Qatar University, the USA, led by Geoffrey Thün at the University of Michigan, the Netherlands, led by Andy van den Dobbelsteen at Delft University of Technology, the United Kingdom, led by Greg Keeffe at Queens University Belfast, and Australia (collaborator, led by Rob Roggema). Local governments, companies and communities are involved in the activities of the national teams. We are grateful to JPI Europe Urban for initiating the "Sustainable Urbanization Global Initiative-Food-Water-Energy Nexus" and making the M-NEX project possible.

\section{Conflict of Interests}

The authors declare no conflict of interest.

\section{References}

Abdul, S. P., Shrestha, S., Pandey, V. P., \& Anal, A. K. (2017). Water-energy-food nexus: Principles and practices. Washington, DC: American Geophysical Union.

Al-Saidi, M., \& Elagib, N. A. (2017). Towards understanding the integrative approach of the water, energy and food nexus. Science of the Total Environment, 574, 1131-1139.

Allan, J. A. (2003a). Useful concept or misleading metaphor? Virtual water: A definition. Water International, 28(1), 4-11.

Allan, J. A. (2003b). Virtual water: The water, food, and trade nexus useful concept or misleading metaphor? Water International, 28(1), 4-11.

Ames, R. T., \& Hershock, P. D. (2015). Value and values: Economics and justice in an age of global interdependence. Honolulu, HI: University of Hawaii Press.

Andersson, E., \& Barthel, S. (2016). Memory carriers and stewardship of metropolitan landscapes. Ecological Indicators, 70, 606-614.

Artioli, F., Acuto, M., \& McArthur, J. (2017). The waterenergy-food nexus: An integration agenda and implications for urban governance. Political Geography, 61, 215-223.

Bai, X. (2018). Sustainability will be won or lost in cities. Environmental Prize. Retrieved from www. environment-prize.com/press-room/press/2018--sustainability-in-cities

Barthel, S., \& Isendahl, C. (2013). Urban gardens, agriculture, and water management: Sources of resilience for long-term food security in cities. Ecological Economics, 86(October), 224-234.

Bazilian, M., Rogner, H., Howells, M., Hermann, S., Arent, D., Gielen, D., \& Yumkella, K. K. (2011). Consid- ering the energy, water and food nexus: Towards an integrated modelling approach. Energy Policy, 39(12), 7896-7906.

Bears, R. (2017). The green economy and the waterenergy-food nexus. Basingstoke: Palgrave Macmillan.

Bergvall-Kåreborn, B., Howcroft, D., Ståhlbröst, A., \& Melander, A. (2010). Participation in living lab: Designing systems with users. In International Federation for Information Processing 2010 (pp. 317-326). Laxenburg: IFIP.

Bergvall-Kåreborn, B., Holst, M., \& Ståhlbröst, A. (2009). Concept design with a living lab approach. Proceedings of the 42nd Annual Hawaii International Conference on System Sciences, HICSS, 1-10.

Bettencourt, L., \& West, G. (2010). A unified theory of urban living. Nature, 467(7318), 912-913.

Bhaduri, A., Ringler, C., Dombrowski, I., Mohtar, R., \& Scheumann, W. (2015) Sustainability in the waterenergy-food nexus. Water International, 40(5/6), 723-732.

Bjögvinsson, E., Ehn, P., \& Hillgren, P. (2012). Design things and design thinking: Contemporary participatory design challenges. Technology, 28(3), 101-116.

Bohn, K., \& Viljoen, A. (2011). The edible city: Envisioning the continuous productive urban landscape (CPUL). Field Journal, 4(1), 149-161. Retrieved from www.field-journal.org/index.php?page=issue-4

Buchanan, R. (2010). Wicked problems in design thinking. Revista KEPES, 7(6), 7-35. https://doi.org/ $10.2307 / 1511637$

Cabinet. (2018). Models for future SDGs cities. Kantei.Go. Retrieved from www.kantei.go.jp/jp/singi/ tiiki/kankyo

Carpenter, S. R., Booth, E. G., Gillon, S., Kucharik, C. J., Loheide, S., Mase, A. S., . . . Wardropper, C. B. (2015). Plausible futures of a social-ecological system: Yahara watershed, Wisconsin, USA. Ecology and Society, 20(2). http://dx.doi.org/10.5751/ES-07433-200210

Choi, Y., \& Suzuki, T. (2013). Food deserts, activity patterns, \& social exclusion: The case of Tokyo, Japan. Applied Geography, 43, 87-98.

City of Chicago. (2009). Our city, our future. Chicago, IL: City of Chicago. Retrieved from http://www. omahabydesign.org/wp-content/uploads/2011/02/ CHICAGO-Climate-Chagnge-Action-Plan.pdf

Costanza, R., D’Arge, R., Groot, R., Farber, S., Grasso, M., Hannon, B., . . . Belt, M. (1997). The value of the world's ecosystem services and natural capital. $\mathrm{Na}$ ture, 387, 253-260.

Cusinato, A. (2016). A comment on Scott and Storper's "The nature of cities: The scope and limits of urban theory". Papers in Regional Science, 95(4), 895-901.

Daher, B. T., \& Mohtar, R. H. (2015). Water-energy-food (WEF) nexus tool 2.0: Guiding integrative resource planning and decision-making. Water International, 40(5/6), 748-771.

Endo, A., \& Oh, T. (2018). The water-energy-food nexus: Human-environmental security in the Asia-Pacific 
ring of fire. Singapore: Springer.

Endo, A., Tsurita, I., Burnett, K., \& Orencio, P. M. (2014). A review of the current state of research on the water, energy, and food nexus. Journal of Hydrology: Regional Studies, 11, 20-30.

Engelhard, B. (2010). Rooftop to tabletop: Repurposing urban roofs for food production. Washington, DC: University of Washington. Retrieved from www.city farmer.org/Benn\%20Engelhardroofoptabletop.pdf

FAO. \& UNEP. (1999). The future of our land: Facing the challenge. Guidelines for Integrated Planning for Sustainable Management of Land Resources. Rome: FAO \& UNEP. Retrieved from www.fao.org/ docrep/004/x3810e/x3810e00.htm

Farr, D. (2012). Sustainable urbanism: Urban design with nature. Hoboken, NJ: Wiley.

Freiburg. (2018). Germany-Freiburg-Green city. EcoTipping Point. Retrieved from www.ecotipping points.org/resources.html

Gómez-Baggethun, E., \& Barton, D. N. (2013). Classifying and valuing ecosystem services for urban planning. Ecological Economics, 86, 235-245.

Gondhalekar, D., \& Ramsauer, T. (2017). Urban climate nexus city: Operationalizing the urban water-energyfood nexus for climate change adaptation in Munich, Germany. Urban Climate, 19, 28-40.

Greater Sydney Commission. (2018). A metropolis of three cities; Greater Sydney regional plan. Sydney: State of New South Wales. Retrieved from www. greater.sydney/metropolis-of-three-cities

Groenfeldt, D. (2006). Multifunctionality of agricultural water: Looking beyond food production and ecosystem services. Irrigation and Drainage, 55(August), 73-83.

Haase, D., Haase, A., \& Rink, D. (2014). Conceptualizing the nexus between urban shrinkage and ecosystem services. Landscape and Urban Planning, 132, 159-169.

Hara, Y., Mcphearson, T., Sampei, Y., \& Mcgrath, B. (2018). Assessing urban agriculture potential: A comparative study of Osaka, Japan and New York city, United States. Sustainability Science, 13, 937-952.

Hoff, H. (2011). Understanding the nexus. Background paper for the Bonn2011 Nexus Conference. Stockholm: Stockholm Environment Institute.

Hussey, K., \& Pittock, J. (2012). The energy-water nexus: Managing the links between energy and water for a sustainable future. Renewable and Sustainable Energy Reviews, 17(1). http://dx.doi.org/10.5751/ES04641-170131

IPCC. (2014). Summary for policymakers. In Climate change 2014: Impacts, adaptation, and vulnerability. Part A: Global and sectoral aspects (pp. 1-32). Cambridge: Cambridge University Press. Retrieved from www.ipcc.ch/report/ar5/wg2

IPCC. (2018). Global warming of $1.5^{\circ} \mathrm{C}$ (IPCC Report SR15). Retrieved from report.ipcc.ch/sr15/pdf/ sr15_spm_final.pdf
IRENA. (2015). Renewable energy in the water, energy and food nexus. Abu Dhabi: Irena. Retrieved from www.irena.org/documentdownloads/publications/ irena_water_energy_food_nexus_2015.pdf

Johansson, J., Schmid Neset, T. S., \& Linnér, B. O. (2010). Evaluating climate visualization: An information visualization approach. In Proceedings of the International Conference on Information Visualisation (pp. 156-161). Salermo: University of Salermo.

Kimbell, L. (2011). Rethinking design thinking: Part I. Design and Culture, 3(3), 285-306.

Kimbell, L. (2012). Rethinking design thinking: Part II. Design and Culture, 4(2), 129-148.

Kurian, M., \& Ardakanian, R. (2015). Governing the nexus: Water, soil and waste resources considering global change. New York, NY: Springer.

Lawson, L. (2016). Sowing the city. Nature, 540, 522-524.

Liu, J., Hull, V., Godfray, H. C. J., Tilman, D., Gleick, P., Hoff, H., . . . Li, S. (2018). Nexus approaches to global sustainable development. Nature Sustainability, 1(9), 466-476.

Loftus, A. (2009). Intervening in the environment of the everyday. Geoforum, 40(3), 326-334.

Magis, K. (2010). Community resilience: An indicator of social sustainability. Society Natural Resources, 23(5), 401-416. https://doi.org/10.1080/ 08941920903305674

Martínez-Martínez, L., \& Calvo, J. (2010). The growing problem of antibiotic resistance in clinically relevant Gram-negative bacteria: Current situation. Enfermedades Infecciosas y Microbiología Clínica, 28(July), 25-31.

McCalla, A. (1997). The water, food, and trade nexus. Paper presented at the MENA-MED Conference, World Bank, in Marrakesh.

McClintock, N. (2010). Why farm the city? Theorizing urban agriculture through a lens of metabolic rift. Cambridge Journal of Regions, Economy and Society, 3(2), 191-207.

Meeus, S. J., \& Gulinck, H. (2008). Semi-urban areas in landscape research: A review. Living Reviews in Landscape Research, 2. https://doi.org/10.12942/Irlr2008-3

Merrett, S. (2003). Virtual water and the Kyoto consensus. Water International, 28(4), 540-542.

Mitchell, T., \& Harris, K. (2012). Resilience: A risk management approach. London: The Overseas Development Institute. Retrieved from https://www.odi.org/ sites/odi.org.uk/files/odi-assets/publications-opinion -files/7552.pdf

Mok, H. F., Williamson, V. G., Grove, J. R., Burry, K., Barker, S. F., \& Hamilton, A. J. (2014). Strawberry fields forever? Urban agriculture in developed countries: A review. Agronomy for Sustainable Development, 34(1), 21-43.

Moreno-Peñaranda, R. (2011). Japan's urban agriculture: Cultivating sustainability and well-being. Our World. Retrieved from ourworld.unu.edu/en/japans-urban- 
agriculture-cultivating-sustainability-and-wellbeing

Morgan, K. (2009). Feeding the city: The challenge of urban food planning. International Planning Studies, 14(4), 341-348.

Moss, R. H., Edmonds, J. A., Hibbard, K. A., Manning, M. R., Rose, S. K., van Vuuren, D. P., . . . Wilbanks, T. J. (2010). The next generation of scenarios for climate change research and assessment. Nature, 463(7282), 747-756.

Mougeot, L. J. A. (2000). Urban agriculture: Definition, presence, potentials and risks, and policy challenges. International Development Research Center. Retrieved from idl-bnc-idrc.dspacedirect. org/bitstream/handle/10625/26429/117785.pdf?se quence $=12$

Munksgaard, J., Pedersen, K. A., \& Wien, M. (2000). Impact of household consumption on $\mathrm{CO}_{2}$ emissions. Energy Economics, 22(4), 423-440.

Nature. (2010). The century of the city. Nature, 467(October), 900-901.

NDRC. (2008). China's policies and actions for addressing climate change. The national development and reform commission. Carnegie Endowment. Retrieved from carnegieendowment.org/files/ WHITE_PAPER_ON_CLIMATE_CHANGE-EN.pdf

Parshall, L., Gurney, K., Hammer, S. A., Mendoza, D., Zhou, Y., \& Geethakumar, S. (2010). Modeling energy consumption and $\mathrm{CO}_{2}$ emissions at the urban scale: Methodological challenges and insight from the United States. Energy Policy, 38, 4765-4782.

Powell, L. (2016). Urban sustainability. Nature, 536(August), 391-393.

Rogelj, J., Den Elzen, M., Höhne, M., Franzen, T., Fekete, H., Winkler, H., . . . Meinshausen, M. (2016). Paris Agreement climate proposals need a boost to keep warming well below $2^{\circ} \mathrm{C}$. Nature, 534, 631-639.

Romero-lankao, P., \& Gnatz, D. M. (2016). Conceptualizing urban water security in an urbanizing world. Current Opinion in Environmental Sustainability, 21, 45-51.

Romero-lankao, P., Mcphearson, T., \& Davidson, D. J. (2017). The food-energy-water nexus and urban complexity. Nature Climate Change, 7(4), 233-235.

Sachs, I. (1980). Developing in harmony with nature: Consumption patterns, time and space uses, resources profiles and technological choices. Canadian Journal of Development Studies, 1(1), 154-175.

Sachs, I. (1988). Work, food and energy in urban ecodevelopment. Economic and Political Weekly, 23(9), 425-434.

Sanyé-Mengual, E., Anguelovski, I., Oliver-Solà, J., Montero, J. I., \& Rieradevall, J. (2016). Resolving differing stakeholder perceptions of urban rooftop farming in Mediterranean cities: Promoting food production as a driver for innovative forms of urban agriculture. Agriculture and Human Values, 33(1), 101-120.

Siddiqi, A., \& Anadon, L. D. (2011). The water-energy nexus in Middle East and North Africa. Energy Policy,
39(8), 4529-4540.

Stead, D. (2012). Best practices and policy transfer in spatial planning. Planning Practice and Research, 27(1), 103-116.

Stead, D., \& Pojani, D. (2018). Learning across cities and regions: The limits to transferring "best practice". In N. F. Dotti (Ed.), Knowledge, policymaking and learning for european cities and regions: From research to practice (pp. 58-68). Cheltenham: Edward Elgar Publishing.

Steffen, W., Richardson, K., Rockström, J., Cornell, S. E., Fetzer, I., Bennett, E. M., . . . Sörlin, S. (2015). Planetary boundaries: Guiding human development on a changing planet. Science, 347(6223), 1259855.

SUGI. (2016). Sustainable Urbanisation Global Initiative (SUGI)/Food-water-energy nexus. Urban Europe. Retrieved from jpi-urbaneurope.eu/calls/sugi

Tanaka, T. (2003). A study on the volume and transportation distance as to food imports ("food mileage") and its Influence on the Environment. Journal of Agricultural Policy and Research, 5, 45-59.

The Economist. (2011, June 23). Where do you live? The Economist. Retrieved from www. economist. com/special-report/2011/06/23/where-do-you-live

The Guardian. (2018, October 12). More than a million UK residents live in 'food deserts', says study. The Guardian. Retrieved from www.theguardian. com/society/2018/oct/12/more-than-a-million-ukresidents-live-in-food-deserts-says-study

Thieme, T., \& Kovacs, E. (2015). Services and slums: Rethinking infrastructures and provisioning across the nexus. Nexus Network Think Piece Series, 4(4). Retrieved from www.thenexusnetwork.org/ wp-content/uploads/2014/08/ThiemeandKovacs_ ServicesandSlumsNexusThinkpiece2015.pdf

Thinyane, M., Terzoli, A., Thinyane, H., Hansen, S., \& Gumbo, S. (2012). Living lab methodology as an approach to innovation in ICT4D: The Siyakhula living lab experience. Paper presented at IST-Africa 2012.

Thomas, R., Pojani, D., Lenferink, S., Bertolini, L., Stead, D., \& van der Krabben, E. (2018). Is transit-oriented development (TOD) an internationally transferable policy concept? Regional Studies, 52(9), 1201-1213.

Tornaghi, C. (2014). Critical geography of urban agriculture. Progress in Human Geography, 38(4), 551-567.

Townsend, A. (2013). Smart cities: Buggy and brittle. Places Journal. Retrieved from placesjournal.org/ article/smart-cities

Tratalos, J., Fuller, R. A., Warren, P. H., Davies, R. G., \& Gaston, K. J. (2007). Urban form, biodiversity potential and ecosystem services. Landscape and Urban Planning, 83(4), 308-317.

UN. (2018). World urbanization prospects 2018. UN.org. Retrieved from www.un.org/development/ desa/en/news/population/2018-revision-of-worldurbanization-prospects.html

Urban Nexus. (2013a). Health and quality of life in urban areas. Urban nexus WP3 synthesis report. Urban 
Nexus. Retrieved from http://www.ectp-ceu.eu/ images/stories/PDF-docs/Health\%20and\%20Quality \%20of\%20life\%20Sythesis\%20Report\%20WP3.pdf

Urban Nexus. (2013b). Competing for urban land. Nexus synthesis report. Urban Nexus. Retrieved from https://www.mistraurbanfutures.org/en/publication/ competing-urban-land-synthesis-report-urban-nexus

Urban Nexus. (2013c). Urban climate resilience. Synthesis report. Urban Nexus. Retrieved from https://www. mistraurbanfutures.org/en/project/urban-nexus

Varbanov, P. S. (2014). Energy and water interactions: Implications for industry. Current Opinion in Chemical Engineering, 5, 15-21.

Venkatesh, G., Chan, A., \& Bratteb $\varnothing$, H. (2014). Understanding the water-energy-carbon nexus in urban water utilities: Comparison of four city case studies and the relevant influencing factors. Energy, 75, 153-166.

Verburg, P. H., Mertz, O., Erb, K. H., Haberl, H., \& $\mathrm{Wu}, \mathrm{W}$. (2013). Land system change and food security: Towards multi-scale land system solutions. Current Opinion in Environmental Sustainability, 5(5), 494-502.

Vogt, K. A., Patel-Weynand, T., Shelton, M., Vogt, D. J., Gordon, J. C., Mukumoto, C. T., . . . Roads, P. A. (2010). Sustainability unpacked: Food energy and water for resilient environments and society. New York, NY: Earthscan Publications Ltd.

von Heland, J. (2011). Rowing social-ecological systems: Morals, culture and resilience. Stockholm: Stockholm University. Retrieved from www.diva-portal. org/smash/get/diva2:441732/FULLTEXT01.pdf

Voytenko, Y., McCormick, K., Evans, J., \& Schliwa, G. (2016). Urban living labs for sustainability and low carbon cities in Europe: Towards a research agenda. Journal of Cleaner Production, 123(August), 45-54.

Wackernagel, M., \& Rees, W. (1998). Our ecological foot- print: Reducing human impact on the Earth. Gabriola Island: New Society Publishers.

Wahl, D. C., \& Baxter, S. (2008). The designer's role in facilitating sustainable solutions. Design Issues, 24(2), 72-83. https://doi.org/10.1162/desi.2008.24.2.72

Walker, R. E., Keane, C. R., \& Burke, J. G. (2010). Disparities and access to healthy food in the United States: A review of food deserts literature. Health and Place, 16(5), 876-884.

White, D. D., Wutich, A. Y., Larson, K. L., \& Lant, T. (2015). Water management decision makers' evaluations of uncertainty in a decision support system: The case of WaterSim in the Decision Theater. Journal of Environmental Planning and Management, 58(4), 616-630.

Whittinghill, L. J., \& Rowe, D. B. (2012). The role of green roof technology in urban agriculture. Renewable Agriculture and Food Systems, 27(4), 314-322.

Wolsink, M. (2012). The research agenda on social acceptance of distributed generation in smart grids: Renewable as common pool resources. Renewable and Sustainable Energy Reviews, 16(1), 822-835.

Wongbumru, T., \& Bart, D. (2014). Smart communities for future development: Lessons from Japan. Built, 3, 69-75. Retrieved from http://www.built journal.org/built_issue_3/05\%20Review\%20Article. pdf

World Bank. (2018). Urban development. World Bank. Retrieved from www.worldbank.org/en/topic/ urbandevelopment/overview

Yan, W., \& Galloway, B. (2017). Rethinking resilience: Adaptation and transformation. New York, NY: Springer.

Yokohari, M., \& Amati, M. (2005). Nature in the city, city in the nature: Case studies of the restoration of urban nature in Tokyo, Japan and Toronto, Canada. Landscape and Ecological Engineering, 1(1), 53-59.

\section{About the Authors}

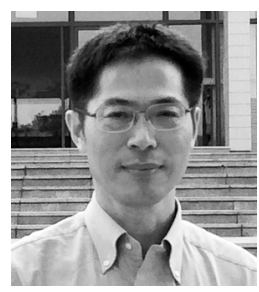

Wanglin Yan (PhD) is Professor at the Faculty of Environmental Information Studies, Keio University, and head of Program for Environmental Design and Governance at the Graduate School of Media and Governance of the same university. Prof. Yan is a distinguished scholar in Environmental and Geo-informational Science for urban and regional planning by multi-disciplinary and transdisciplinary approaches. He has led the sub-regional node of Asia-Pacific Adaptation Network of UNEP and is devoted to climate change adaptation and disaster risk reduction in Japan and northeast Asian countries. Recently he is leading the consortium of M-NEX and studying on co-creative design for communitybased sustainability.

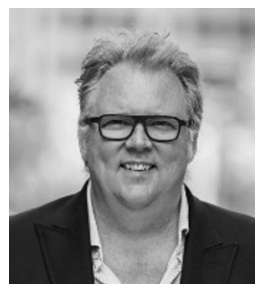

Rob Roggema $(\mathrm{PhD})$ is Professor of Sustainable Spatial Transformations at the Knowledge Centre Noorderruimte, Hanze University Groningen. He is a landscape architect and an internationally renowned design-expert on sustainable urbanism, climate adaptation, energy landscapes and urban agriculture. He has previously held positions at universities in the Netherlands and Australia, State and Municipal governments and design consultancies. Rob developed the Swarm Planning concept, a dynamic way of planning the city for future adaptation to the impacts of climate change. 